\title{
Sinkronisasi Kewenangan Regulasi Pemerintah Kabupaten/Kota sebagai Model Implementasi Kebijakan Ekonomi Nasional yang Mendukung Iklim Investasi di Daerah
}

\author{
F.C. Susila Adiyanta \\ Fakultas Hukum, Universitas Diponegoro \\ susilafhundip@gmail.com
}

\begin{abstract}
This study aims to Synchronize the Authority of Regency / City Government Regulations as a Model of the Implementation of National Economic Policies that Support the Investment Climate in the Region. By using a statute approach and empirical approach, this research is carried out to identify regulatory authorities and solutions to problems in regional regulations that are not conducive to national policies on investment in the region. The results of the study obtained conclusions: a) the characteristics and problems of regional regulations in supporting the implementation of investment policies in regions categorized into general and specific characteristics. General characteristics include legal products that have juridical problems, substance, and legal principles, while special characteristics are problems related to supporting legal products that can affect the business climate and competitiveness of investment, spatial planning, and regional institutions; b) Measures for governance of regional regulations to support the implementation of national economic policies that are conducive to investment for investment require planning, design, and preparation of comprehensive regional regulations by synchronizing the content of regional regulations involving all elements in the region, namely: executive institutions, legislative, business actors, and the community. Some recommendations from the results of this study are: a) local governments need to increase institutional capacity, innovation, and public services; b) the existence of experts who can be a reference in the design and preparation of regional regulations that are conducive to the investment climate and business competitiveness; c) in the preparation and design of regional regulations it is necessary to further increase access to public participation.
\end{abstract}

Keywords: National Economic Policy, Regional Regulations, Investment

\begin{abstract}
Abstrak
Penelitian ini bertujuan untuk Sinkronisasi Kewenangan Regulasi Pemerintah Kabupaten/Kota sebagai Model Implementasi Kebijakan Ekonomi Nasionalyang Mendukung Iklim Investasi di Daerah. Dengan menggunakan pendekatan perundangundangan (statute approach) dan empiris (empirical approach), penelitian ini dilakukan untuk mengidentifikasi kewenangan regulasi dan model solusi permasalahan peraturan daerah yang tidak kondusif bagi kebijakan nasional tentang investasi di daerah. Hasil kajian diperoleh kesimpulan : a) karakteristik dan kebermasalahan peraturan daerah dalam mendukung implementasi kebijakan investasi di daerah kategorikan ke dalam karakteristik umum dan khusus. Karakteristik umum meliputi produk-produk hukum yang mempunyai kebermasalahan yuridis, substansi, dan prinsip-prinsip hukum, sedangkan karakteristik
\end{abstract}


khusus adalah kebermasalahan yang berkaitan dengan produk-produk hukum pendukung yang dapat mempengaruhi iklim usaha dan daya saing investasi, tata ruang, dan kelembagaan daerah; b) Langkah-langkah solutif tata kelola peraturan daerah untuk mendukung implementasi kebijakan ekonomi nasional yang kondusif bagi investasi bagi investasi memeerlukan perencanaan, perancangan, dan penyusunan peraturan derah yang komprehensif dengan sinkronisasi materi muatan peraturan daerah yang melibatkan semua elemen di daerah, yaitu: lembaga eksekutif, legislatif, pelaku usaha, dan masyarakat. Beberapa rekomendasi dari hasil penelitian ini adalah : a) pemerintah daerah perlu meningkatkan kapasitas kelembagaan, inovasi, dan pelayanan publik; b) adanya tenaga ahli yang dapat menjadi rujukan dalam perancangan dan penyusunan peraturan daerah yang kondusif bagi iklim investasi dan daya saing usaha; c) dalam penyusunan dan perancangan peraturan derah perlu lebih meningkatkan akses partisipasi publik.

Kata kunci: Kebijakan Ekonomi Nasional, Peraturan Daerah, Investasi

\section{A. Pendahuluan}

Pemerintah kabupaten/kota mempunyai posisi strategis dalam sebagai penanggungjawab utama dalam merencanakan dan sekaligus dalam merealisasikan tujuan utama penyelenggaran kesejahteran umum. Dengan adanya kewenangan berdasarkan asas otonomi, pemerintah kabupaten/ kota mempunyai keleluasaan untuk merencanakan dan mengelola potensi, sumber-sumber kekayaan dan sumber daya manusia di daerah.

Penyelenggaraan otonomi daerah dengan titik berat otonomi pada daerah kabupaten/kota, menuntut adanya kesiapan sumber daya, sumber dana, responsibilitas, akuntabilitas, serta pranata sosial dari setiap pemerintah kabupaten/kota, sehingga mampu untuk menerima hak, wewenang, dan tanggung jawab yang lebih besar dari pemerintah pusat dan/atau pemerintah propinsi. Kewenangan daerah otonom ini berbeda dengan kewenangan yang dipraktekkan pada masa rezim orde baru yang sangat sentralistik. Pada masa orde baru, Pemerintah pusat sering bertindak kurang adil dalam pembagian pendapatan dan kekayaan yang ada di daerah-daerah. Hubungan keuangan pusat dan daerah dimanapun dipandang sangat menentukan dalam kemandirian otonomi daerah.

Dengan demikian, pemahaman akan tuntutan atas hak dalam mengelola rumah tangganya sendiri sangat wajar, sebab sistem pemerintahan sentralistik yang selama ini terjadi telah menguras kekayaan dan sumber alam yang dimiliki daerah. Pada sisi lain, kewenangan yang otonom yang dimiliki pemerintah daerah kabupaten dan kota pasca orde baru, memberi ruang bagi pemerintah di daerah untuk mengelola potensi dan sumber keyaan daerah secara sektoral, bahkan secara ekstrim bertentangan dan bertolak belakang dengan kebijakan yang ditetapkan secara nasional.

Persoalan yang muncul kemudian adalah minimnya sumber keuangan yang dimiliki daerah dibandingkan dengan yang dimiliki oleh pemerintah pusat. Pemerintah daerah yang 
tidak siap secara ekonomi, manajemen, dan birokrasi, serta kurang didukung sumber daya alam maupun sumber daya manusia, dalam proses transisi ini berupaya sekuat tenaga untuk membenahi daerahnya dengan bekal kekuasaan otonom dan desentralisasi kewenangan yang dimilikinya ${ }^{1}$.

Banyak produk peraturan daerah yang dibuat untuk memanfaatkan potensi sumber daya alam daerah, sehingga cenderung mengeksploitasi dan merusak alam serta lingkungan. Begitu pula daerah-daerah yang tidak mempunyai sumber daya alam, tetapi lebih banyak memiliki potensi sumber penerimaan keuangan dari sektor jasa, ekonomi, dan peraturan derahgangan, membuat peraturan-peraturan tentang pajak, retribusi atas jasa dan pelayanan publik yang justru menghambat kegiatan usaha, menjadi beban bagi masyarakat luas, yang pada sisi lain justru membuka peluang bagi aparat untuk memanfaatkan kesempatan atas kewenangan birokrasi yang dipegangnya ${ }^{2}$.

Berbagai peraturan daerah dibuat dengan tanpa adanya pertimbangan, tanpa koordinasi dengan pemerintah daerah, pemerintah pusat maupun lembaga-lembaga yang terkait dengan peraturan yang dibuat pemerintah daerah tersebut. Peraturan-peraturan dan kebijakan daerah yang dalam pembuatannya dimaksudkan untuk mengoptimalkan penerimaan daerah, justru berbalik arah menjadi tidak kondusif bagi investasi dan pertumbuhan ekonomi. Pada sisi lain, kebijakan-kebijakan yang dibuat pemerintah daerah tersebut menjadi tidak populis dan cenderung membebani masyarakat.

Hasil Survei yang telah dilakukan oleh Bappenas dan Lembaga Pengembangan Ekonomi Manajemen Universitas Indonesia (LPEM UI) tahun 2008 terhadap 200 perusahaan memperlihatkan bahwa prosedur perizinan, waktu, dan biaya yang dibutuhkan untuk proses ekspor dan impor merupakan faktor utama penghambat berinvestasi di Indonesia, yang diikuti dengan kondisi makro-ekonomi dan ketersediaan infrastruktur ${ }^{3}$. Sebagian besar permasalahan yang dihadapi untuk meningkatkan investasi adalah : pertama, belum optimalnya pelaksanaan harmonisasi pusat dan daerah - terutama terkait dengan kewenangan dan tata kelola regulasi perizinan dan prosedur investasi di daerah yang kurang sederhana, kedua, kualitas infrastruktur yang kurang memadai, ketiga, masih cukup

\footnotetext{
${ }^{1}$ Christian von Luebke (Australian National University) melalui penelitiannya (2006) juga membuktikan bahwa kepala daerah menjadi penentu kualitas peraturan daerah, Harian Bisnis Indonesia - Sabtu, 01 September 2007 - Hal. B11

${ }^{2}$ Pemerintah terus mengevaluasi peraturan daerah dan rancangan peraturan daerah yang membebani masyarakat dan pelaku usaha. Sampai pertengahan Juli, dari 7.200 peraturan yang dievaluasi Direktorat Jenderal Perimbangan Keuangan, sebanyak 2.000 peraturan tentang pungutan daerah diusulkan diusulkan untuk ditolak dan direvisi, Harian Koran Tempo, 23 Juli 2008

${ }^{3}$ Laporan Tahunan dan Survey Bappenas dan Lembaga Pengembangan Ekonomi Manajemen Universitas Indonesia (LPEM UI) tahun 2008, https://www.lpem.org/id/?s=iklim+investasi diunduh tanggal $30 \mathrm{Mei}$ 2019
} 
panjangnya perizinan investasi, sehingga masih menyebabkan tingginya biaya perizinan investasi dibandingkan dengan negara-negara kompetitir, keempat, belum tercukupinya pasokan energi yang dibutuhkan untuk kegiatan industri, kelima masih cukup banyak peraturan daerah yang menghambat iklim investasi, keenam, masih terkonsentrasinya sebaran investasi di Pulau Jawa, dan belum optimalnya pelaksanaan alih teknologi ${ }^{4}$.

Implikasi lebih lanjut dari munculnya berbagai produk peraturan daerah yang tumpang tindih, baik antara peraturan-peraturan daerah yang sudah ada, antara peraturan daerah dengan peraturan perundang-undangan yang diatasnya, serta bertentangan dengan peraturan-peraturan lain yang terkait pada akhirnya memunculkan kontroversi dan permasalahan dalam pelaksanaannya. Semua itu berakibat pada pencabutan peraturanperaturan daerah yang bermasalah tersebut oleh pemerintah pusat ${ }^{5}$.

Untuk mengatasi berbagai permasalahan terkait dengan regulasi dan prosedur perizinan yang tidak mendukung iklim dan daya saing investasi di daerah, Pemerintah melalui Paket Kebijakan Ekonomi X memperlonggar investasi sekaligus meningkatkan perlindungan bagi usaha mikro, kecil, menengah dan koperasi. Dengan melalui Paket Kebijakan Ekonomi X, Pemerintah menambah 19 bidang usaha yang dicadangkan untuk Usaha Mikro, Kecil, Menengah, dan Koperasi (UMKMK) dalam revisi Peraturan Presiden Nomor 39 Tahun 2014 tentang Daftar Bidang Usaha yang Tertutup dan Bidang Usaha yang Terbuka dengan Persyaratan di Bidang Penanaman Modal atau yang lebih dikenal sebagai Daftar Negatif Investasi (DNI). Dalam konferensi pers saat mengumumkan Paket Kebijakan Ekonomi X di Istana Kepresidenan, Jakarta (11/2), Menteri Koordinator Bidang Perekonomian Darmin Nasution menjelaskan, ke-19 bidang usaha itu tercakup dalam kegiatan jenis usaha jasa bisnis/jasa konsultasi konstruksi yang menggunakan teknologi sederhana/madya dan/atau resiko kecil/sedang dan/atau nilai pekerjaan kurang dari Rp 10 milyar ${ }^{6}$.

Dalam DNI sebelumnya, dipersyaratkan adanya saham asing sebesar 55\% di bidangbidang usaha seperti jasa pra design dan konsultasi, jasa design arsitektur, jasa administrasi kontrak, jasa arsitektur lainnya,dan sebagainya. Selain itu terdapat 39 bidang usaha yang dicadangkan untuk UMKMK diperluas nilai pekerjaanya dari semula sampai dengan Rp 1 miliar menjadi sampai dengan Rp 50 miliar. Kegiatan itu mencakup jenis usaha jasa

\footnotetext{
${ }^{4}$ Loc.cit.

${ }^{5}$ Hingga akhir Desember 2008 terdapat 8.219 Peraturan Daerah (Peraturan derah) yang dievaluasi. Dari jumlah tersebut, sebanyak 34 persen atau sekitar ada 2.779 peraturan derah bermasalah dan dibatalkan atau direkomendasikan untuk direvisi. Dirjen Perimbangan Keuangan Depkeu Mardiasmo, di Jakarta, Rabu (31/12) menyebutkan bahwa hingga Desember ada 34 persen peraturan derah bermasalah.

${ }^{6}$ Harian Kompas tanggal 11 Februari 2018 dan Harian Kontan tanggal 11 Februari 2018
} 
konstruksi, seperti pekerjaan konstruksi untuk ba bangunan komersial, bangunan sarana kesehatan, dan lain-lain. Untuk memperluas kegiatan usaha UMKMK itu dilakukan reklasifikasi dengan menyederhanakan bidang usaha ${ }^{7}$.

Berangkat dari latar belakang penelitian tersebut di atas, artikel ini hendak memberikan deskripsi atas hasil kajian penelitian dengan pendekatan perundang-undangan untuk mengidentifikasi permasalahan dalam perancangan dan penetapan materi muatan peraturan daerah dan juga menggunakan pendekatan empiris (untuk memberikan deskripsi realitas tentang model penyelesaian dalam bentuk sinkronisasi materi muatan dan tat kelola peraturan daerah dengan kebijakan nasional khususnya untuk mendukung implementasi paket kebijakan nasional dibidang investasi) yang telah ditetapkan oleh Pemerintah.

Dalam artikel ini rumusan penelitian yang menjadi fokus kajian penelitian, telaah dan pembahasan adalah sebagai berikut: Bagaimana karakteristik dan kebermasalahan peraturan daerah dalam mendukung implementasi kebijakan ekonomi nasional tentang investasi di daerah. Bagaimana langkah-langkah solutif tata kelola peraturan daerah untuk mendukung implementasi paket kebijakan ekonomi nasional yang kondusif bagi investasi.

\section{B. Pembahasan}

\section{Indetifikasi Karakteristik Peraturan Daerah untuk Mendukung Implementasi Kebijakan Ekonomi Nasional tentang Investasi di Daerah}

Sejak otonomi daerah, pemerintah daerah memperoleh kewenangan untuk mengurus dirinya sendiri. Untuk dapat mengurus dirinya sendiri tersebut, pemerintah daerah memperoleh kewenangan yang luas. Pemerintah daerah bersama lembaga legislatif daerah mempunyai kewenangan untuk menetapkan peraturan daerah. Materi muatan suatu peraturan daerah menurut UU No. 12 Tahun 2011 tentang Pembentukan Peraturan Perundangundangan adalah seluruh materi muatan dalam rangka penyelenggaraan otonomi daerah dan tugas pembantuan (medebewind), termasuk pula menampung kondisi khusus daerah serta penjabaran lebih lanjut peraturan perundang-undangan yang lebih tinggi. Selain itu, pemerintah daerah juga mempunyai kewenangan untuk menerbitkan produk hukum daerah lainnya, yaitu: peraturan kepala daerah, dan keputusan kepala daerah ${ }^{8}$.

\footnotetext{
${ }^{7}$ Loc.cit.

${ }^{8}$ Dalam konsideran huruf a UU No. 12 Tahun 2011 tentang Pembentukan Peraturan Perundang-undangan disebutkan bahwa tujuan dari pembentukan UU adalah untuk mewujudkan Indonesia sebagai negara hukum, negara berkewajiban melaksanakan pembangunan hukum nasional yang dilakukan secara terencana, terpadu, dan berkelanjutan dalam sistem hukum nasional yang menjamin pelindungan hak dan kewajiban segenap rakyat Indonesia berdasarkan Undang-Undang Dasar Negara Republik Indonesia
} 
Ada beberapa teori yang dikenal untuk mengidentifikasi permasalahan suatu rancangan peraturan derah, diantaranya adalah: metode ROCCIPI (Rule, Opportunity, Capacity, Communication, Interest, Process, dan Ideology), metode Fishbone, dan RIA. (Regulatory Impact Assesment). Pada metode ROCCIPI, beberapa hal yang obyek telaah/identifikasi adalah berkaitan dengan ${ }^{9}$ : peraturan (rule); kesempatan (opportunity); Kemampua (Capacity); Komunikasi (Communication); Kepentingan (Interest); Proses (Process); dan Idiologi (Idiology)

Pada metode fishbone, riset dilakukan secara mendalam, segala hal diuji dalam sebuah diskusi yang panjang. Beberapa hal yang diuji adalah terkait dengan ${ }^{10}$ :

a. Men (manusia), dilakukan pengujian bagaimana perilaku manusia (subyek hukum) melaksanakan atau bertindak sehingga timbul masalah.

b. Money (uang/anggaran), pengujian dilakukan dengan mengidentifikasi bagaimana kedudukan anggaran dalam pelaksanaan kegiatan sehingga menimbulkan masalah.

c. Management, dilakukan pengujian dan riset apakah pola manajerial baik dari sistem maupun sub sistem dapat mendukung atau tidak terhadap aturan-aturan yang ada. Perlu diperbaharuikah aturan yang lama atau membentuk aturan yang baru.

d. Method (metode), yang dimaksud metode disini adalah terkait dengan hubungan antara subyek hukum (pelaku) dengan obyek hukum, bagaimana model dan pola hubungannya tersusun dalam sebuah metode.

e. Environment (lingkungan), lingkungan sangat berpengaruh terhadap hadirnya persoalan yang terjadi, lingkungan ini terkait juga pengaruh dari luar (globalisasi).

Metode fishbone ini dilakukan jika memang analisa terhadap suatu permasalahan muncul ketika suatu peraturan akan diterapkan.

Metode lainnya yang dikenal dalam mempersiapkan suatu peraturan daerah adalah metode RIA (Regulatory Impact Assesment). Metode RIA ini lebih mengutamakan pemahaman terhadap segala peraturan dibalik penyusunan peraturan yang baru. RIA biasanya digunakan sebagai jaminan untuk mendukung pembangunan dan investasi. Penggunaan RIA harus dilakukan riset yang mendalam kenapa peraturan tersebut diterbitkan. Setelah hal tersebut terjawab, apa resikonya jika peraturan tersebut diadakan. Jika hal-hal

\footnotetext{
${ }^{9}$ LGSP, Seri Penguatan Legislatif: Legal Drafting, Penyusunan Peraturan Daerah, Buku Pegangan untuk DPRD, Local Governance Support Program, Jakarta, 2007, hlm. 9

${ }^{10} \mathrm{Ibid}, \mathrm{hlm} .19$
} 
tersebut telah terjawab maka sebuah peraturan akan terlihat baik dan buruknya jika diterapkan dalam masyarakat ${ }^{11}$.

Metode-metode yang dikenal, yaitu metode ROCCIPI (Rule, Opportunity, Capacity, Communication, Interest, Process, dan Ideology), metode fishbone, dan RIA (Regulatory Impact Assesment), oleh beberapa daerah belum banyak diterapkan untuk penyusunan dan perancangan peraturan daerah. Metode ini sebetulnya menjembatani metode-metode yang telah dikenal dalam penyusunan dan perancangan peraturan derah. Apabila dalam metode ROCCIPI (Rule, Opportunity, Capacity, Communication, Interest, Process, dan Ideology) dilakukan riset secara mendalam sebelum disusunnya suatu rancangan peraturan derah. Begitu pula dengan metode fishbone yang dilakukan, jika memang analisa terhadap suatu permasalahan muncul ketika suatu peraturan akan diterapkan dan metode RIA (Regulatory Impact Assesment) yang lebih mengutamakan pemahaman terhadap segala peraturan dibalik penyusunan peraturan yang baru.

Kendala yang ada diantarnya adalah tidak banyak atau bahkan belum adanya kesiapan sumber daya manusia yang mempunyai ekspertasi di bidang perancangan undang-undang (legal drafting). Lembaga-lembaga ekesekutif dan legislatif dalam merancang dan menyusun produk-produk peratutan daerah lebih banyak menggunakan SDM yang tersedia di lembaga masing-masing meskipun tidak semua memiliki ekpertasi di bidang perancangan undangundang (legal drafting) $)^{12}$.

Suatu catatan dalam implementasi metode-metode perancangan undang-undang tersebut adalah masih banyaknya produk peraturan daerah yang dihasilkan oleh pemerintah daerah yang bermasalah baik permasalahan yuridis, substantif, maupun permasalahan lainnya yang seharusnya tidak perlu terjadi atau paling tidak bisa menjadi instrumen preventif dalam mengatasi permasalahan hukum yang terjadi dalam penyusunan dan perancangan peraturan daerah.

Secara ideal, suatu peraturan daerah tidak hanya sebagai peraturan pelaksana dari peraturan yang dibuat oleh pemerintah pusat, tetapi juga sebagai pencerminan aspirasi masyarakat di daerah. Hal ini mengingat bahwa pada dasarnya fungsi hukum adalah sebagai instrumen bagi kontrol sosial (social control) dan rekayasa sosial (social enginering) masyarakat. Namun dalam praktek pelaksanaannya, banyak produk hukum peraturan daerah yang buat oleh pememrintah daerah tidak memenuhi kebutuhan dan aspirasi masyarakat

\footnotetext{
${ }^{11}$ Loc.cit.

${ }^{12}$ Hasil wawancara dengan beberapa pejabat eksekutif dan legislatif di masing-masing kabupaten dan kota tempat penelitian dilakukan
} 
bahkan banyak diantaranya bertentangan dengan pandangan yang berkembang dan mencederai keadilan masyarakat ${ }^{13}$.

Ketentuan dalam UU No. 12 Tahun 2011 tentang Pembentukan Peraturan Perundang-undangan dan juga UU No. 23 Tahun 2014 tentang Pemerintah Daerah, memberikan kewenangan kepada daerah untuk membuat peraturan daerah (perda) sebagai payung hukum dalam pelaksanaan urusan di daerah. Dalam pembuatan regulasi tersebut, daerah juga harus mengacu kepada hirarki tata peraturan perundangan di Indonesia. Kebijakan publik yang dikristalkan dalam bentuk regulasi tentu mengatur seluruh aspek kehidupan masyarakat baik ekonomi, sosial, politik dan budaya.

Dalam bidang ekonomi, kebijakan haruslah mendorong penciptaan iklim usaha yang baik. Penetapan kebijakan seharusnya memudahkan pelaku ekonomi untuk menjalankan usahanya $^{14}$. Menurut pengertian Organisation for Economic Co-operation and Development (OECD) "Regulation is of critical importance in shaping the welfare of economies and society. The objective of regulatory policy is to ensure that regulation works eff ectively, and is in the public interest) ${ }^{\prime \prime 15}$. Dengan demikian, regulasi tidak diterbitkan begitu saja, namun perlu dikaji lebih dalam agar berdampak bagi kesejahteraan masyarakat.

Berdasarkan kajian Komite Pemantauan Pelaksanaan Otonomi Daerah (KPPOD) terbaru, dari 1.082 Peraturan Daerah (Perda) yang dikaji, lebih dari 50 persen bermasalah. Sepanjang 2016, pada gelombang I terdapat 383 Perda yang dikaji, dan 172 di antaranya dinyatakan bermasalah. Selanjutnya pada gelombang II, dari 507 perda terdapat 262 perda yang bermasalah. Dan yang terakhir, pada gelombang III terdapat 152 Perda yang dinyatakan bermasalah dari total 410 Perda yang dikaji. Perda yang belum terkaji akan masuk ke gelombang selanjutnya ${ }^{16}$.

\footnotetext{
${ }^{13} \mathrm{Ma}$ 'aruf, Ahmad. Strategi Pengembangan Investasi di Daerah: Pemberian Insentif ataukah Kemudahan? Yogyakarta: 2012

${ }_{15}^{14}$ Pudyatmoko, Sri. Perizinan: Problem dan Upaya Pembenahan. Jakarta: Grasindo, 2009

15 Terjemahan bebas: "Peraturan merupakan hal penting sebagai instrumen untuk membangun kesejahteraan ekonomi dan masyarakat. Tujuan dari regulasi adalah untuk memastikan peraturan yang dibuat telah berjalan dengan efektif dan mewakili kepentingan publik", OECD. Regulatory Policy and Governance: Supporting Economic Growth and Serving the Public Interest. OECD Publishing: 2011

${ }^{16}$ Berapa Jumlah Peraturan Daerah yang Bermasalah" https://databoks.katadata.co.id/datapublish/2017/04/07/berapa-jumlah-peraturan-daerah-yang-bermasalah diunduh pada tanggal 22 Mei 2019
} 
Grafik. 1. Jumlah Peraturan Daerah yang Bermasalah

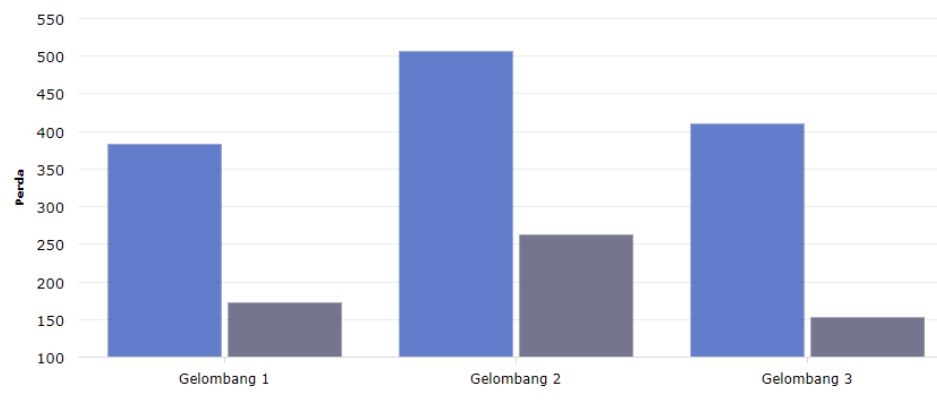

Sumber: Kata Data https://databoks.katadata.co.id/datapublish/2017/04/07/berapajumlah-peraturan- daerah-yang-bermasalah diunduh tanggal 25 Mei 2019

Dari kajian KPPOD terhadap peraturan daerah di kabupaten-kabupaten dan kota di Indonesia terdapat peraturan daerah yang mempunyai permasalahan yang ringan seperti salah ketik, tidak meng -up date- dasar hukum yang termuat dalam konsideran, serta beberapa permasalahan ringan lainnya. Selain itu juga terdapat sejumlah peraturan daerah yang memiliki permasalahan yang berat, sehingga direkomendasikan supaya direvisi atau bahkan dibatalkan ${ }^{17}$.

Dari hasil evaluasi pemerintah, ditemukan 3.143 peraturan bermasalah. Pemerintah membatalkan ribuan aturan tersebut berdasarkan kajian dan pertimbangan bahwa peraturan daerah tersebut menghambat upaya perbaikan kemudahan berusaha dan peningkatan daya saing nasional. Pembatalan peraturan bermasalah ini menjadi strategi pemerintah pusat untuk meningkatkan peringkat Ease of Doing Business Indonesia.

Pembatalan peraturan itu sesuai dengan instruksi Presiden Joko Widodo (Jokowi) kepada Kementerian Dalam Negeri. Dalam instruksinya, pemerintah menyatakan bahwa jika suatu preaturan tingkat daerah menyulitkan masyarakat, Presiden Jokowi memerintahkan untuk langsung menghapus peraturan tersebut tanpa perlu melakukan kajian. Aturan yang dibatalkan meliputi pencabutan peraturan daerah atau direvisi oleh Menteri Dalam Nnegeri (Mendagri) dan gubernur serta peraturan dan keputusan Mendagri. Jenis-jenis aturan bermasalah yang dibatalkan meliputi peraturan yang menghambat pertumbuhan ekonomi daerah dan perpanjangan jalur birokrasi, menghalangi kemudahan usaha, mempersulit proses perizinan dan investasi, serta bertentangan dengan perundangan yang lebih tinggi. ${ }^{18}$

\footnotetext{
17 Dari kajian yang dilakukan KPPOD terhadap 1381 peraturan daerah, sekitar $31 \%$ diantaranya bermasalah (KPPOD. Evaluasi Perda Pungutan di Era UU No.28 Tahun 2009. Jakarta: 2014).

${ }^{18}$ Widyanita, "Pembatalan $\quad 3.143 \quad$ Peraturan Bermasalah", dari https://katadata.co.id/infografik/2016/06/23/pembatalan-3143-peraturan-bermasalah pada tanggal 28 Mei 2019
} 
Gambar 1. Infografik 7 (Tujuh) Provinsi dengan Pembatalan Peraturan Daerah Terbanyak

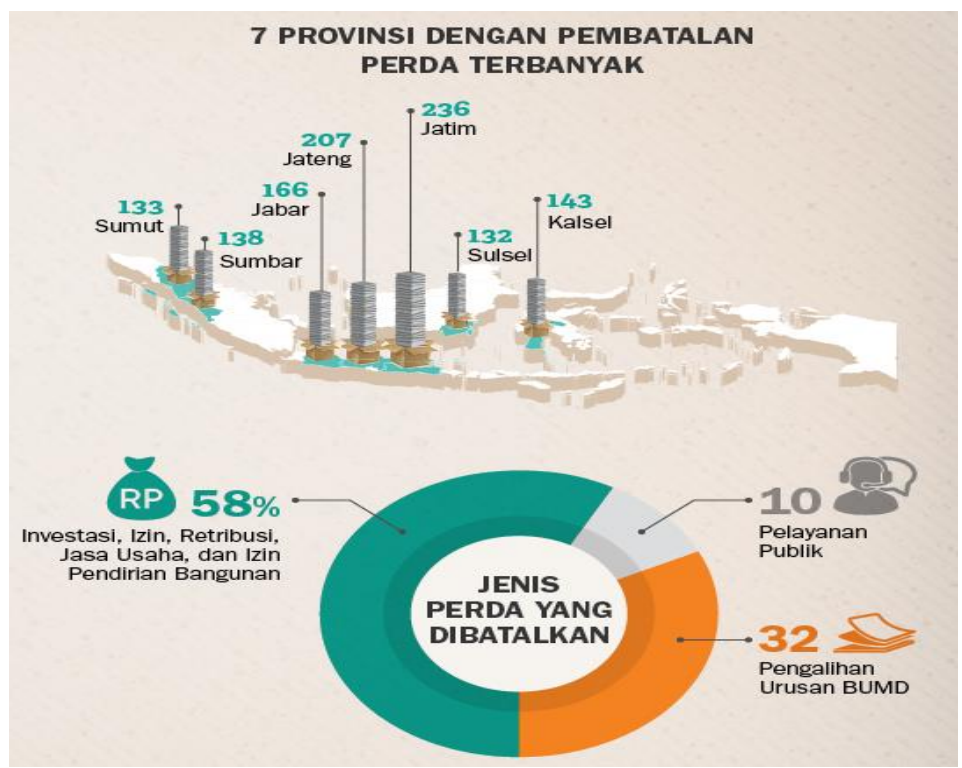

Sumber: https://www.google.com/search?q=infografis+sinkronisasi+perda+yang+menghambat+investasi\&safe

Permasalahan mengenai produk peraturan daerah sebagaimana telah ditemukan oleh KPPOD juga dapat dilihat dari survei di beberapa kabupaten dan kota di Indonesia. Di beberapa kabupaten terdapat beberapa produk hukum dan kebijakan daerah yang menimbulkan beberapa masalah yuridis. Demikian pula dalam pelaksanaan kewenangan oleh pemerintah daerah dan kota. Terdapat beberapa persoalan ketika kebijakan otonomi daerah mulai diterapkan. Kenyataan tersebut menunjukkan kapasitas DPRD dan pemerintah tingkat kabupaten dalam melaksanakan tanggungjawab baru dan menetapkan rencana pembangunan pemerintah di tingkat daerah secara menyeluruh untuk di setiap kabupaten masih dipertanyakan.

\section{Gambar 2 Grafik Kebermasalahan Aspek Substansi Peraturan Daerah ${ }^{19}$}

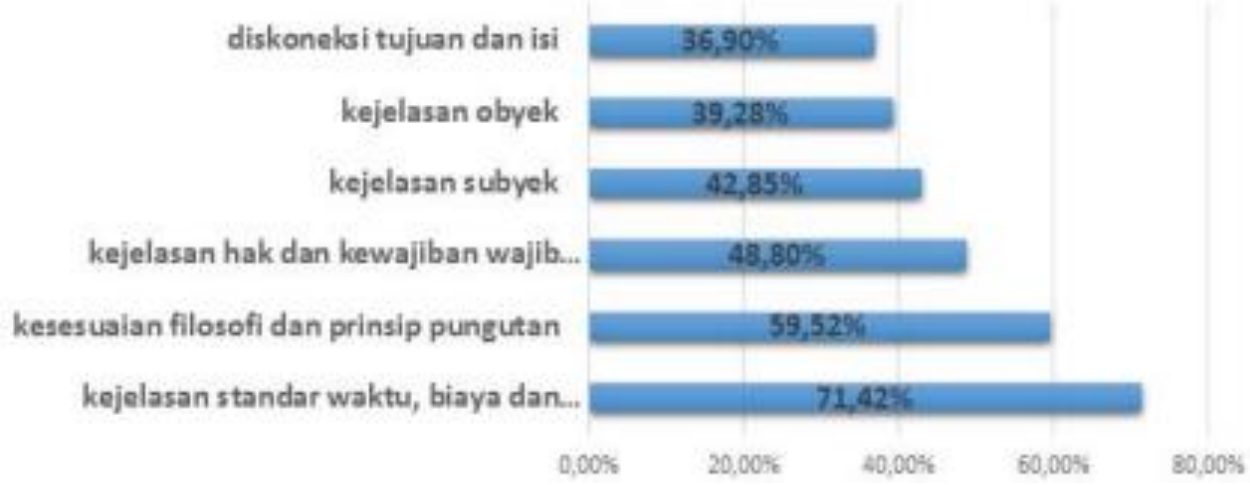

${ }^{19}$ Hasil Penelitian "Regulasi Usaha di Daerah Kajian Perda Pungutan dan Peizinan" yang dilakukan oleh H. Nurcahyadi Suparman (et.al) https://www.kppod.org/backend/files/laporan_penelitian/kajian-perdapungutan-dan-perizinan.pdf pada tangga 22 Mei 2019 
Sumber: https://www.kppod.org/backend/files/laporan_penelitian/kajian-perda-pungutan-dan-perizinan.pdf pada tangga 22 Mei 2019

Kecenderungan kebermasalahan terbesar yang diperlihatkan oleh peraturan daerahperaturan daerah yang dianalisis adalah kebermasalahan substansi, disusul kemudian dengan kebermasalahan yuridis. Kebermasalahan substansi dari peraturan daerah-peraturan daerah yang dianalisis terutama terletak pada ketidaksesuaian filosofi dan prinsip pungutan, diikuti oleh ketidakjelasan prosedur dan birokrasi pelayanan, serta ketidakjelasan obyek yang diatur oleh peraturan daerah-peraturan daerah tersebut. Sementara itu kebermasalahan yuridis dari peraturan daerah-peraturan daerah yang dianalisis terutama adalah pada masih digunakan acuan yuridis formal yang sudah dinyatakan tidak berlaku lagi dan atau sudah diubah (acuan yuridis yang digunakan sudah tidak up to date lagi), dalam kaitannya dengan pelaksanaan otonomi daerah.

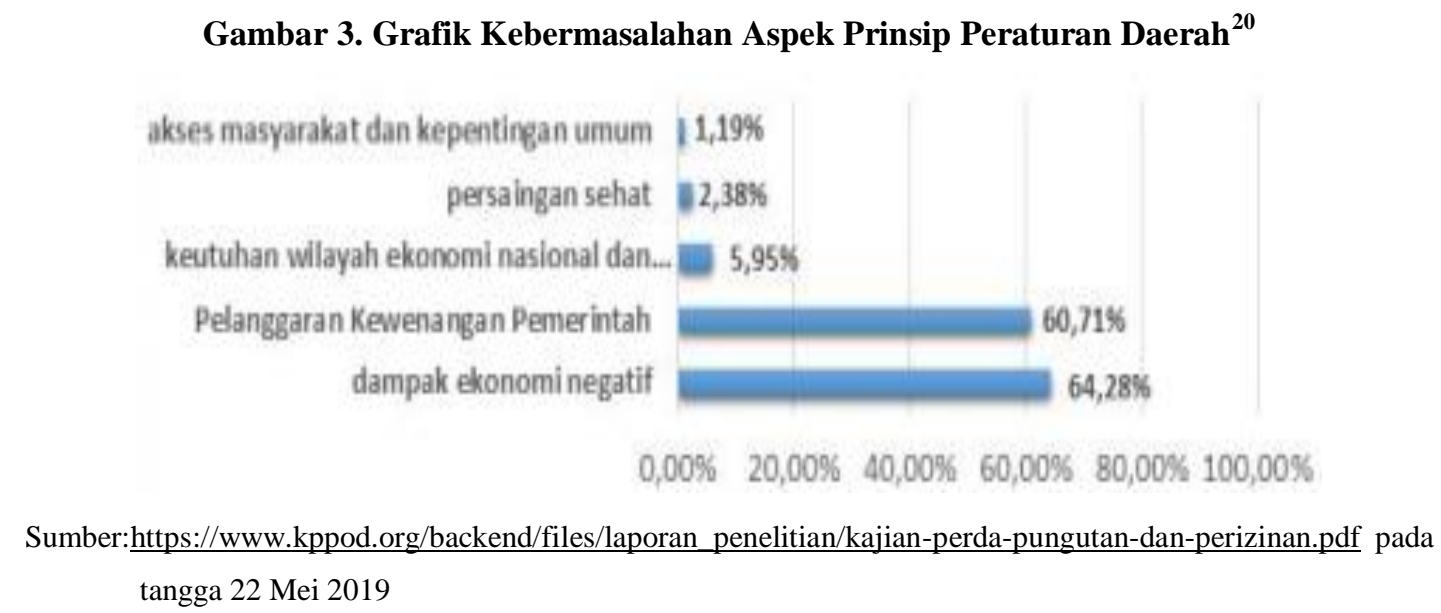

Salah satu langkah yang diambil oleh pemerintahan era Presiden Joko Widodo saat ini adalah mempercepat deregulasi untuk meningkatkan iklim investasi. Hal ini dilakukan dengan menerbitkan sejumlah paket kebijakan untuk menggairahkan kembali perekonomian nasional, total 15 buah, selama 2015 sampai 2017. Sebaliknya, lebih dari 3000 Perda yang dipandang menghambat investasi dipangkas. Dampaknya, peringkat Indonesia dalam Indeks Kemudahan Berbisnis World Bank meningkat dari peringkat 120 di 2015, menjadi 106 di 2016 hingga 91 di 2017. Kondisi ini masih jauh dari sempurna tapi menunjukkan peningkatan. Untuk mengatasi kondisi regulasi di tingkat daerah yang tidak mendukung bagi kegiatan investasi, Pemerintah Pusat menyebutkan bahwa masih banyak yang harus dilakukan sebagai langkah pembenahan berbagai prosedur admnistrasi dan tata kelola regulasi dibidang investasi di berbagai daerah di Indonesia, diantaranya adalah

\footnotetext{
${ }^{20}$ Loc.cit.
} 
penyederhanaan serta pembenahan perijinan, peraturan yang tumpang tindih, termasuk deregulasi Daftar Negatif Investasi (DNI) ${ }^{21}$.

Langkah deregulasi peraturan daerah yang dinilai menghambat kegiatan investasi dan ekonomi semakin berat. Hal tersebut karena Mahkamah Konstitusi (MK) memutuskan pembatalan Perda tingkat kabupaten/kota oleh gubernur atau menteri bertentangan dengan UUD 1945. Seperti diketahui, selama jalannya otonomi daerah, yaitu sekitar 17 tahun, pemerintah pusat telah membatalkan sekitar 4.000 Perda yang bermasalah. Jumlah tersebut lebih tinggi dibandingkan dengan capaian yang dilakukan oleh MA yang hanya membatalkan kurang dari 100 Perda $^{22}$.

\section{Sinkronsisasi Kewenangan dan Materi Muatan Peraturan Daerah: Solusi untuk Mendukung Iklim Investasi yang Kondusif}

Daerah otonom sebagai satuan pemerintahan mandiri yang memiliki wewenang atributif-lebih-lebih sebagai subyek hukum (publieck rechtpersoon, public legal entity), mempunyai kewenangan membuat peraturan-peraturan untuk menyelenggarakan rumah tangganya sendiri ${ }^{23}$. Wewenang mengatur ini ada pada pemerintah daerah (pejabatan administrasi negara) dan DPRD sebagai lembaga legislatif daerah. Peraturan daerah sebagai produk hukum merupakan pelaksanaan fungsi legislatif DPRD. Wewenang pembentukan peraturan daerah ini dilakukan bersama antara gubernur, bupati, walikota.

Dengan adanya kewenangan pemerintah derah untuk merancang dan menetapkan peraturan di tingkat daerah kabupaten dan kota, pemerintah daerah bersama lembaga legislatif dengan demikian juga mempunyai kewenangan untuk mengatur tentang rencana tata kelola ekonomi daerah untuk mengoptimalkan potensi sumber daya manusia dan sumber daya alam di daerah secara maksimal bagi tujuan kesejahteraan masyarakt di daerah. Dengan demikian tata kelola ekonomi daerah merupakan salah satu bagian dari fungsi pemerintahan daerah dalam menjalankan otonomi daerah.

Dalam tata kelola ekonomi daerah, pemerintah daerah menerbitkan sejumlah kebijakan perekonomian daerahnya dan menjalankannya untuk pelayanan aktivitas ekonomi di daerah yang bersangkutan. Kebijakan dan pelayanan aktivitas perekonomian dalam konteks penelitian ini, dapat menjadi pendorong atau sebaliknya penghambat bagi para

\footnotetext{
${ }^{21}$ Indonesia Baik, Masa Pemerintahan Jokowi: Mempercepat Dereguilasi, Mempercepat Investasi; pada https://indonesiabaik.id/infografis/masa-pemerintahan-jokowi-mempercepat-deregulasi mempercepatinvestasi diunduh dari laman pada tanggal 23 Mei 2019

${ }^{22}$ Loc.cit.

${ }^{23}$ Bagir Manan, Menyongsong Fajar Otonomi Daerah, Pusat Studi Hukum UII, Jogjakarta, 2002, halaman70
} 
pelaku usaha yang menjalankan bisnisnya di setiap daerah tersebut. Dengan kata lain, tata kelola ekonomi daerah merupakan tata kelola pemerintahan daerah dalam memberikan pelayanan terhadap aktivitas ekonomi bagi pelaku usaha di setiap kabupaten/kota.

Peraturan Daerah, sebagai suatu kerangka acuan hukum dalam pelaksanaan kebijakan di daerah, merupakan aspek penting yang diperhatikan oleh para pelaku usaha. Tidak sedikit kalangan dunia usaha merasa terbebani oleh ketentuan-ketentuan yang diatur dalam peraturan daerah. Berdasarkan kenyataan itulah, suatu untuk mengimplentasikan dan mendukung paket kebijakan nasional di bidang investasi di daerah, sejak dalam proses perancangan suatu peraturan daerah perlu dilakukan suatu sinkronisasi materi muatan peraturan daerah terhadap produk-produk hukum peraturan daerah sebelum diundangkan maupun pada saat dilaksanakan ${ }^{24}$.

Sinkronisasi materi muatan peraturan daerah dapat digunakan sebagai alternatif dalam mengatasi secara preventif berbagai permasalahan hukum dari produk-produk hukum peraturan daerah. Metode alternatif ini digunakan pada saat suatu produk hukum peraturan da masih dalam bentuk rancangan (draft) yang diajukan oleh pihal eksekutif maupun legislatif. Dengan dasar kriteria yang telah ditetapkan -yang diantaranya telah disebutkan pada bahasan sub bab sebelumnya- dapat diklasifikasikan produk peraturan daerah yang memenuhi syarat yuridis, substantif, maupun syarat-syarat prinsip dalam perancangan (legal drafting) dan penyusunan peraturan daerah.

Gambar 4. Infografik Interaksi Pemerintah Daerah dengan Pelaku Usaha

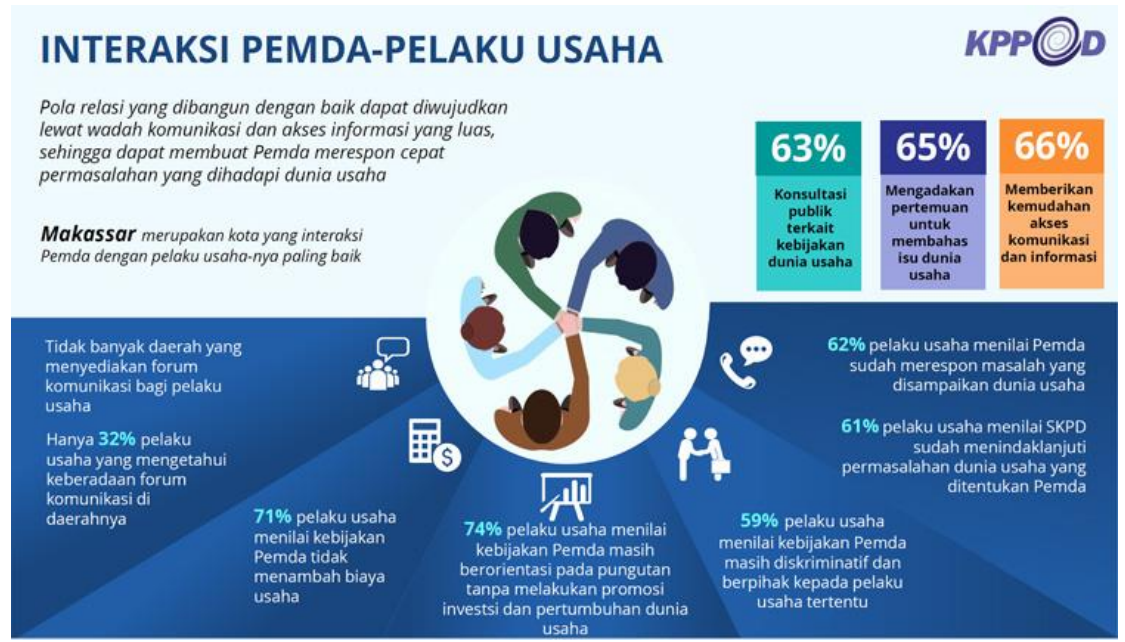

Sumber:https://www.google.com/search?safe=strict\&rlz=1C1DIEZ_enID743ID792\&biw=1366\&bih=625\&tbm=isch\&sa=1\&ei= 1PrwXKu8Ftzez7sPkceSsAI\&q=infografik+otonomi+daerah\&oq=infografik+otonomi+daerah\&gs_l=img.12.

\footnotetext{
${ }^{24}$ Pasal 1 angka 13 UU No. 12 Tahun 2011 menyebutkan bahwa materi muatan peraturan perundangundangan adalah materi yang dimuat dalam peraturan perundang-undangan sesuai dengan jenis, fungsi, dan hierarki peraturan perundang-undangan. Lihat pula Pasal 6 UU No. 12 Tahun 2011
} 
Sinkronisasi regulasi antara pemerintah Pusat dengan daerah dapat dilakukan, jika dalam perancangan peraturan ditingkat pusat dan daerah terjalin koordinasi, komunikasi dan kesepahaman akan tujuan kebijakan ekonomi nasional yang mendukung investasi di daerah adalah untuk kepentingan kesejahteraan umum dan bukan hanya bersifat sektoral semata. Demikian pula bila ada ruang interaksi antara Pemerintah Pusat, Pemerintah Daerah dan pelaku usaha. Pola relasi yang baik antara pemerintah dengan pelaku usaha, investor sebagai pemangku kepentingan dapat diwujudkan melalui sarana komunikasi dan akses informasi yang luas kepada masyarakat, sehingga dapat menampung aspirasi yang mewakili kepentingan masyarakat dapat direspon oleh pemeerintah daerah dengan cepat untuk memberikan respon terhadap berbagai permasalahan yang dihadapi dunia usaha ${ }^{25}$.

Di dalam praktek penyelenggaraan pelayanan publik, prosedur pelayanan perizinan, banyak permasalahan yang tidak mendapat respon yang cepat dan solusi yang tepat, tidak banyak pemerintah daerah yang meyediakan forum komunikasi bagi pelaku usaha untuk mengatasi permasalahan pelayanan yang mendukung kegiatan usaha dan investasi di daerah, oelh KPPOD disebutkan hanya Pemeritah Kota Makassar merupakan kota yang melakukan interaksi terbaik dengan para pelaku usaha. Hanya $32 \%$ pelaku usaha yang mengetahui keberadaan forum komunikasi di daerahnya. Terhadap kebijakan pemerintah daerah, $74 \%$ pelaku usaha menilai bahwa kebijakan yang dibuat masih berorientasi pada pemungutan, tanpa melakukan promosi investasi dan pertumbuhan dunia usaha. Begitu pula dalam hal substansi/materi muatan regulasi daerah, $59 \%$ pelaku usaha menilai kebijakan pemerintah daerah masih diskriminatif dan berpihak kepada pelaku usaha tertentu ${ }^{26}$.

Gambar 4. Model Proses Sinkronisasi Materi Muatan Peraturan Daerah

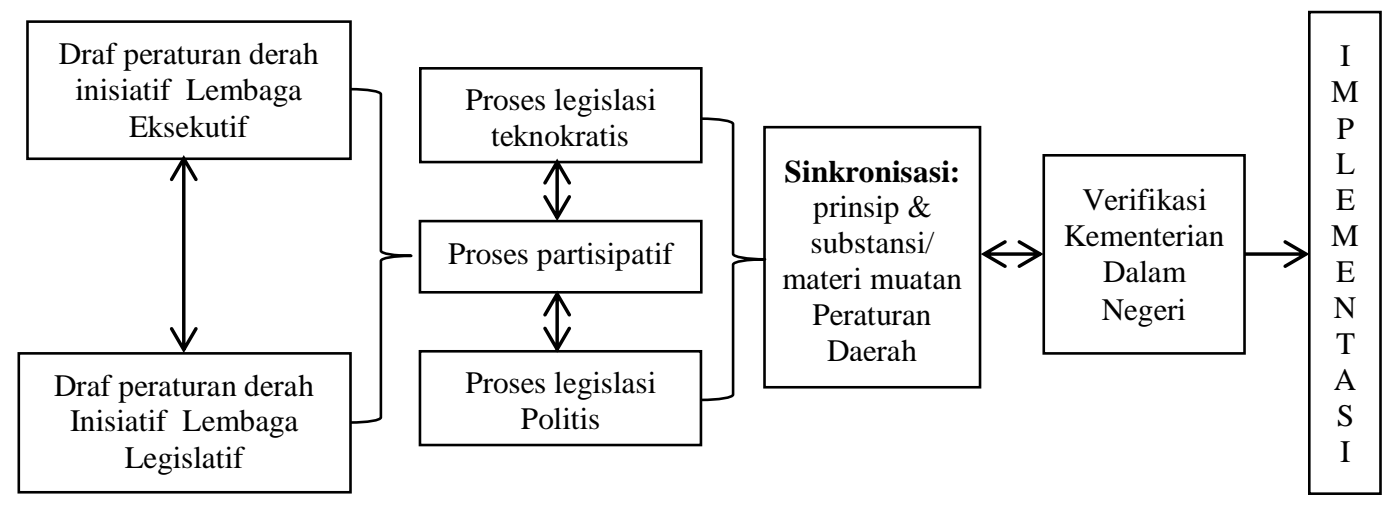

\footnotetext{
${ }^{25}$ Sumber:https://www.google.com/search?safe=strict\&rlz=1C1DIEZ_enID743ID792\&biw=1366\&bih=62 $5 \& \mathrm{tbm}=\mathrm{isch} \& \mathrm{sa}=1 \& \mathrm{ei}=1$ PrwXKu8Ftzez7sPkeSsAI\&q=infografik+otonomi+daerah\&oq=infografik+oto nomi+daerah\&gs_l=img. 12 .

${ }^{26}$ Loc.cit.
} 
Demikian pula fungsi sinkronisasi materi muatan peraturan daerah dimaksudkan untuk mengetahui apakah suatu produk peraturan daerah kodusif bagi iklim investasi dan memenuhi kriteria dalam menarik daya saing usaha. Sinkronisasi materi muatan peraturan daerah produk peraturan daerah ini dimaksudkan sebagai model untuk mengantisipasi adanya permasalahan-permasalahan yuridis produk rancangan peraturan derah sebelum disahkan, diundangkan dan dilaksanakan .

Sinkronisasi materi muatan peraturan daerah diposisikan sebagai alternatif yang menjembatani mekanisme dan proses perancangan preaturan daerah. Sinkronisasi materi muatan peraturan daerah dilakukan setelah proses perancangan peraturan derah secara teknokratis, proses partisipatif, dan sebelum proses legislasi politis. Pada titik proses legislasi politis inilah kemungkinan suatu produk hukum peraturan derah mengalami tarik menarik kepentingan antara kekuatan politis dengan standard perancangan hukum yang ideal.

Dapat terjadi pada proses legislasi politis ini, suatu produk hukum peraturan derah secara substansial mengalami perubahan, begitu juga dengan materi muatan yang terkandung dan menjadi fokus dari peraturan derah tersebut akan mengalami perubahan yang signifika, sehingga tidak lagi memenuhi kriteria teknokratis maupun sinkronisasi materi muatan peraturan daerah yang sebelumnya telah dilakukan. Sinkronisasi materi muatan peraturan daerah dapat dilakukan pada saat melakukan perancangan undang-undang (legal drafting) suatu produk hukum peraturan daerah.

Peraturan daerah sebagai pedoman dan dasar dalam penyelenggaraan urusan pemerintahan daerah di dalam menetapkannya senantiasa tidak bisa dilepaskan dengan rakyat di daerah. Sesuai dengan prinsip demokrasi, di mana para wakil rakyat di daerah dan kepala daerah dipilih secara langsung oleh rakyat di daerah, diharapkan mereka senantiasa menjalin komunikasi dengan rakyat terkait dengan pembuatan dan penentuan kebijakan daerah yang dituangkan dalam peraturan daerah. Berdasarkan uraian tersebut, hakekat dari daerah otonom adalah masyarakat daerah yang bersangkutan, dan apabila berkaitan dengan masyarakat maka kunci atau intinya adalah keterlibatan masyarakat / partisipasi masyarakat. Dalam konteks ini yang paling urgen adalah pada penyusunan kebijakan dan implementasinya dalam bentuk peraturan daerah.

Iklim investasi yang baik akan mendorong terjadinya pertumbuhan ekonomi, yakni melalui investasi yang didukung oleh produktivitas yang tinggi. Investasi akan memperkuat pertumbuhan ekonomi dengan mendatangkan lebih banyak input ke dalam proses produksi. Oleh karenanya, memperbaiki iklim investasi merupakan suatu tugas 
yang penting bagi setiap pemerintah, terutama negara-negara yang memiliki daya saing investasi yang rendah seperti Indonesia.

Dalam beberapa tahun terakhir, kondisi iklim investasi di Indonesia dinilai masih memprihatinkan. Beberapa hasil survei lembaga internasional, memperlihatkan bahwa posisi peringkat daya saing investasi Indonesia masih berada pada kelompok peringkat bawah dan selalu berada di bawah negara-negara di Asia Tenggara khususnya ASEAN, seperti Thailand dan Malaysia. Peringkat ini juga cenderung mengalami penurunan secara signifikan. Hal ini menunjukkan seriusnya persoalan iklim investasi di Indonesia.yang harus segera disikapi.

Perbaikan iklim investasi bukan hanya tanggungjawab pemerintah pusat, namun seluruh lapisan pemerintahan dan masyarakat secara umum, agar perekonomian Indonesia segera pulih dari krisis yang berkepanjangan. Kebijakan desentralisasi pemerintahan di Indonesia yang mulai diterapkan sejak tahun 2001 telah mengamanatkan kepada pemerintah daerah untuk turut berperan besar dalam upaya penciptaan iklim investasi yang kondusif di daerahnya. Dengan kewenangan dibidang pemerintahan yang telah diserahkan kepada pemerintah daerah, telah memungkinkan pemerintah daerah untuk lebih leluasa dalam menciptakan iklim investasi di daerahnya masing-masing. Proses pengambilan kebijakan pembangunan yang sebelumnya lebih banyak dikendalikan oleh pemerintah pusat, selanjutnya menjadi lebih dekat pada masyarakat di daerah. Kesiapan dan kemampuan daerah dalam berkreasi, merupakan salah satu penentu keberhasilan pembangunan di daerah termasuk dalam menciptakan iklim investasi yang kondusif.

\section{Simpulan}

Berdasarkan analisis yang telah disampaikan dibagian pembahaasan maka dapat dirumuskan suatu kesimpulan sebagai berikut : Pertama, Karakteristik dan kebermasalahan peraturan daerah dalam mendukung implementasi kebijakan ekonomi nasional tentang investasi di daerah dapat dikategorikan ke dalam karakteristik umum dan khusus. Karakteristik umum meliputi produk-produk hukum yang mempunyai kebermasalahan yuridis, substansi, dan prinsip-prinsip hukum, sedangkan karakteristik khusus adalah kebermasalahan yang berkaitan dengan produk-produk hukum pendukung yang dapat mempengaruhi iklim usaha dan daya saing investasi, diantaranya peraturan derah tentang APBD, tata ruang, kelembagaan daerah, dan lain-lain; Kedua, Langkah-langkah solutif tata kelola peraturan daerah untuk mendukung implementasi kebijakan ekonomi nasional yang kondusif bagi investasi, memerlukan perencanaan, perancangan, dan penyusunan peraturan 
derah yang komprehensif dengan sinkronisasi materi muatan peraturan daerah yang melibatkan pihak-pihak yang berkompeten di bidang perancangan peraturan derah (legal drafting), serta melibatkan semua elemen di daerah, yaitu: lembaga eksekutif, legislatif, pelaku usaha, dan masyarakat.

Adapun Rekomendasi yang dapat diberikan sebagi masukan terkait dengan pembahasan dan analisis hasil penelitian adalah sebagai berikut : 1). Untuk mewujudkan iklim investasi dan daya saing daerah, pemerintah daerah perlu meningkatkan kapasitas kelembagaan, inovasi, dan pelayanan publik; 2). Pemerintah dan lembaga legislatif daerah perlu mempertimbangkan adanya tenaga ahli yang dapat menjadi rujukan dalam perancangan dan penyusunan peraturan daerah yang kondusif bagi iklim investasi dan daya saing usaha; 3). Pemerintah dan lembaga legislatif daerah dalam penyusunan dan perancangan peraturan derah perlu lebih meningkatkan akses partisipasi publik.

\section{Daftar Pustaka}

Bagir Manan, Perjalanan Historis Pasal 18 UUD 1945, Unsika, Karawang, 1993 Menyongsong Fajar Otonomi Daerah, Penerbit PSH Fakultas Hukum UII, Yogyakarta, 2002

Davey, K.J., Pembiayaan Pemerintah Daerah, Praktek-praktek Internasional dan Relevansinya Bagi Dunia Ketiga, Penerbit UI Press, Jakarta, 1988

Gabriel U. Iglesias, Implementation : The Problem of Achieving Results, Eropa, Manila, 1979 Grindle, Merilee and Thomas, John.W. 1991. Public Choices and Policy Change: The Political Economy of Reform in Developing Countries. The John Hopkins University Press, London.

IDS. 2001. Learning Initiative on Citizen Participation and Local Governance. Jakarta: IDS. Josef Riwu Kaho, Analisa Hubungan Pemerintah Pusat dan Daerah di Indonesia, Bina Aksara, Jakarta, 1991

, Prospek Otonomi Daerah di Negara Republik Indonesia, Identifikasi Beberapa Faktor Yang Mempengaruhi Penyelenggaraannya, Rajawali Press, 2002

KPPOD, 2005. Laporan Penelitian Gambaran Iklim Usaha di 20 Daerah Kabupaten/Kota di Indonesia. Jakarta: KPPOD.

Krishmna Darumurti dan Umbu Rauta, Otonomi Daerah Perkembangan Pemikiran dan Pelaksanaan, Citra Aditya Bahkti, Bandung, 2000

Luwihono, Slamet (ed.), Perencanaan dan Penganggaran Partisipatif untuk Good Governance, Bandung: FPPM, 2006.

Partowidagdo, Widjajono, Memahami Analisis Kebijakan: Kasus Reformasi Indonesia, Bandung: Program Studi Pembangunan - ITB, 1999.

Roscoe Pound, The Task of Law, Franklin and Marshal College, Lancaster, Pensilvania, 1994

Rozali Abdullah, Pelaksanaan Otnomi Luas dan Isu Federalisme Sebagai Suatu Alternatif, Rajawali Press, Jakarta, 2002

Smith, S. and A. Martin, "Achieving Sustainability of Biological Conservation: Report of a GEF Thematic Review. Monitoring and Evaluation Working Paper I". Global Environment Facility, 2000. 
Sumarto, Hetifah Sj, Inovasi, Partisipasi dan Good Governance, Jakarta: Yayasan Obor Indonesia, 2003.

Syaukani HR (ed.al), Otonomi Daerah Dalam Negara Kesatuan, Pustaka Pelajar, Jakarta, 2003

Thomson, Ken. 1946. From Neighborhood to Nation: The Democratic Foundations of Civil Society. Tufts University: University Press of New England.

Tifa Foundation, Identifikasi dan Pemetaan Inovasi Program Pemerintah Kabupaten Jembrana. Jakarta: Pusat Kajian Pembangunan Administrasi Daerah dan Kota FISIP UI.

Arnstein, S, 'A Ladder of Citizen Participation in the USA', Journal of the Royal Town Planning Institute, 1971.

Ateng Syafrudin, Butir-butir Bahan pemikiran Reformasi Pengaturan Otonomi Daerah, Makalah Disampaikan Dalam Studi Nasional Mahasiswa FISIP se Indonesia tentang Eksistensi dan Prospek Otonomi Daerah Pasca Orde Baru, Bandung, Tanggal 1-3 Desember 1998

, Prospek Otonomi Daerah Pasca Orde Baru, Makalah Disampaikan Dalam Studi Nasional Mahasiswa FISIP se Indonesia tentang Eksistensi dan Prospek Otonomi Daerah Pasca Orde Baru, Bandung, Tanggal 1-3 Desember 1998

Armida Alisyahbana, Identifikasi Problematika Pelaksanaan UU No. 25 Tahun 1999 tentang Perimbangan Keuangan Antara Pemerintah Pusat dan Pemerintah Daerah, Makalah Seminar Nasional Dalam Rangka Lustrum IV Program Pasca sarjana Upad, Bandung, Tanggal 9 Agustus 1999

Bagir Manan, Hubungan Pusat Daerah Dalam Penyelenggaraan Otonomi Daerah, Seminar Nasional "Otonomi Daerah dan Perimbangan Antara Pusat dan Daerah, Hata Internasional Legal Concelours, Jakarta, Tanggal 20 Juli 1999

Identifikasi Problematika Pelaksanaan UU No. 22 Tahun 1999 tentang Pemerintah Daerah, Makalah Seminar Nasional Dalam Rangka Lustrum IV Program Pasca sarjana Upad, Bandung, Tanggal 9 Agustus 1999

Hetifah Sj Sumarto, "Membangun Partisipasi Warga dalam Tata Pemerintahan di Indonesia: Praktek, Kebijakan, dan Agenda", Local Government Support Program, Civil Society Strengthening Team, Jakarta 2008

Johanes Fernandez, Mencari Bentuk Otonomi Daerah dan Upaya Memacu Pembangunan Regional di Masa Depan, Jurnal Ilmu-ilmu Sosial No 2 Tahun 1992

KPPOD, Laporan Program Review Peraturan derah Tahap II, Kerjasama KPPOD-PEG US AID, Agustus, 2002

, "Panduan Perancangan dan Review Peraturan derah Ramah Investasi Proyek Perbaikan Iklim Investasi Daerah Melalui Penerapan Sistem Perijinan Terpadu dan Penyempurnaan Kualitas Peraturan derah" Proyek Bersama Komite Pemantauan Pelaksanaan Otonomi Daerah (KPPOD)- Europena Commision (EC)Asosiasi Pemerintahan Kota Seluruh Indonesia, 2008

,"Panduan bagi Para Analis Peraturan derah untuk kajian Peraturan derah Kab. Serang, Kota Tangerang, Kota Bitung, dan Kota Tomohon dalam Proyek Perbaikan Iklim Investasi Daerah melalui Penerapan Sistem Perijinan Terpadu dan Penyempurnaan Kualitas Peraturan derah", KPPOD-EU-APEKSI, Jakarta 2008

LGSP, Seri Penguatan Legislatif, Legal Drafting: Penyusunan Peraturan Daerah, Local Government Support Program, 2007

Seri Penguatan Legislatif: Legal Drafting, Penyusunan Peraturan Daerah, Buku Pegangan untuk DPRD, Local Governance Support Program, Jakarta, 2007 
,"Reformasi Organsasi Pengelolaan Keuangan Daerah", Kajian Akademis, Kerjasama antara USAID, LGSP dan Direktorat Jenderal Pemerintahan Umum Departemen Dalam Negeri, Jakarta, 2008

Pantius D, Soeling, Pemberdayaan SDM untuk Peningkatan Pelayanan Publik, Bisnis Birokrasi No. 2/Vol III/Agustus/1997

Ratnawati "Tata Kelola Ekonomi Daerah" dalam KPPOD News, Edisi Januari-April 2008

Trilaksono Nugroho, Reformasi dan Reorietasi Kebijakan Otonomi Daerah dalam Perspektif

Hubungan Pemerintah Pusat dan Daerah, Jurnal Administrasi Negara Universitas Brawijaya, Vol. I. No.1 September 2000

Utang Suwaryo, Deskripsi dan Interpretasi Otonomi Daerah Serta Prospeknya Pada Masa Yang Akan Datang (Pasca Orde Baru), Makalah Disampaikan Dalam Studi Nasional Mahasiswa FISIP Se Indonesia tentang Eksistensi dan Prospek Otonomi Daerah Pasca Orde Baru, Bandung, Tanggal 1-3 Desember 1998

Badan Pusat Stastistik, Kudus Dalam Angka, BPS Propinsi Jawa Tengah, 2001

2002 , Product Domestik Broto (PDBR) Kabupaten Kudus Tahun 2001-

Jurnal Ilmu-ilmu Sosial No 2 Tahun 2008

Harian Kompas Tanggal 26 Pebruari 2008 , 13 Januari, 1 Juni, 28 Juni, 26 Juli, 21 Agustus. dan 2 September 2009

Harian Kompas tanggal 11 Februari 2018 dan Harian Kontan tanggal 11 Februari 2018

Laporan Tahunan dan Survey Bappenas dan Lembaga Pengembangan Ekonomi Manajemen Universitas Indonesia (LPEM UI) tahun 2008

TAP MPR RI No. IV/MPR/ 2000

Anonim, Himpunan Undang-undang tentang Otonomi Daerah Serta Peraturan Pelaksanaannya, Pustaka Antara, Jakarta, 2000

UU No. 34 Tahun 2000 tentang Perubahan Atas UU No. 18 Tahun 1997 tentang Pajak Daerah dan Retribusi Daerah

Anonim, Himpunan Peraturan Pemerintah tentang Pelaksanaan Otonomi Daerah, Pustaka Antara, Jakarta, 2000

Peraturan Pemerintah No. 25 Tahun 1999 tentang Perimbangan Keuangan Antara Pemerintah Pusat dan Pemerintah Daerah

Keputusan Menteri Dalam Negeri No 130-67 Tahun 2002 tentang Pengakuan Kewenangan Kabupaten dan Kota

Surat Edaran Menteri Dalam Negeri No. 130/383/SJ Tanggal 20 Pebruari 2002 tentang Verifikasi Atas Pengakuan Kewenangan Kabupaten dan Kota per Bidang dari Departemen/ Lembaga Pemerintah Non Departemen. 